\title{
Konstytucyjność ustawy „o Zaburzonych". Podstawa PRAWNa IZOLACJI POSTPENALNEJ I NADZORU PREWENCYJNEGO W POLSKIM PORZĄDKU PRAWNYM
}

\author{
Karolina Piech, karolinapiech@poczta.onet.pl \\ Uniwersytet Wrocławski, plac Uniwersytecki 1, 50-137 Wrocław
}

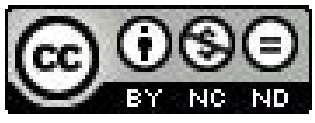

\section{STRESZCZENIE}

Artykuł dotyczy problemu izolacji postpenalnej, wprowadzonej na mocy ustawy z dnia 22 listopada 2013 r., znanej powszechnie jako „ustawa o zaburzonych”. Autorka odnosi się do kwestii zgodności aktu z Konstytucją RP oraz prawem międzynarodowym, a także z zasadami prawa karnego, ukazując problematykę związaną z zakazem retroakcji, zakazem podwójnego karania oraz z naruszeniem zagwarantowanej w ustawie zasadniczej godności człowieka. Poruszone zostały kwestie przedstawiane przez psychologów - problem skuteczności terapii prowadzonej w zakładzie karnym oraz w ośrodku izolacyjnym.

Słowa kluczowe: izolacja postpenalna, lex Trynkiewicz, ustawa o zaburzonych, retroakcja, podwójne karanie

The constitutionality of the law "On perturbed"

\section{Abstract}

This article concerns an issue of a postpenal isolation in Poland, introduced on the strength of an enactment of 22 November 2013 - "enactment about distorted people". An author related to an issue of a compatibility this enactment with Constitution and international law, and rules of criminal law. She featured an issue of a prohibition of retroactive law, a prohibition of a double punishing and a contravention of a dignity of human and educational or rehabilitative function of penalty. An author raised an issue introduced by psychologist - especially an issue of effectiveness of therapy.

Keywords: postpenal isolation, lex Trynkiewicz, enactment about distorted people, retroactive law, double punishment

Niedawno opinia publiczna była świadkiem sytuacji, w której Mariusz T., seryjny morderca i przestępca seksualny, opuszczał zakład karny po odbyciu 25-letniej kary pozbawienia wolności ${ }^{1}$. Został on skazany na karę śmierci w $1988 \mathrm{r}$., jednak w wyniku amnestii z 1989 r. została ona zastąpiona właśnie 25-letnim pozbawieniem wolności². Po opuszczeniu zakładu karnego Mariusz T. początkowo pozostawał pod nadzorem prewencyjnym, jednakże w dniu 30.04.2014 r. został prawomocnie odizolowany w Krajowym Ośrodku Zapobiegania Zachowaniom Dyssocjalnym w Gostyninie. Zdaniem sądu zachodziło bowiem wysokie prawdopodobieństwo popełnienia przez skazanego czynów podobnych do tych, jakich dokonał w przeszłości, o czym świadczyły liczne opinie biegłych. „W ciagu 25 lat odbywania kary pozbawienia wolności nie nastąpiły w jego osobowości zmiany, będące skutkiem przepracowania w terapii problemów emocjonalnych i popędowych. Opiniowany nie uzyskał wglądu w swoje problemy osobowościowe, pozostaje bezkrytyczny w ocenie swoich możliwości przystosowawczych (...). Przedstawił się jako osoba pozbawiona empatii, prezentująca wyuczone wzorce zachowań, jedynie w celu uzyskania korzyści" ${ }^{3}$. Izolacja postpenalna w powyższym przypadku wydaje się być zatem w pełni uzasadniona.

Kontrowersyjna jestjednak kwestia podwójnego karania, ponieważ Mariusz T. odbyłjuż swoją karę i- oczywiście teoretycznie - staje się wolnym człowiekiem. Przyjrzeć należy się najpierw temu, jaka norma prawna zezwala na izolowanie szczególnie niebezpiecznych przestępców, którzy opuszczają zakłady karne. Obecnie tę dziedzinę reguluje ustawa o postępowaniu wobec osób z zaburzeniami psychicznymi stwarzających zagrożenie życia, zdrowia lub wolności seksualnej

1 Zob. I. Kacprzak, G. Zawadka, Trynkiewicz wolny i bez zarzutów, www.rp.pl/artykul/1086195.html, 24.10.2014.

2 Zob. E. Radlińska, Moratorium na karę śmierci bez dożywocia było blędem, www.prawo.gazetaprawna.pl/wywiady/675805,moratorium_na_kare_ smierci_bez_dozywocia_bylo_bledem.html, 24.10.2014.

3 Mariusz Trynkiewicz nie powinien być wolny, www.polskieradio.pl/5/3/Artykul/1043948,Biegli-Mariusz-Trynkiewicz-nie-powinien-byc-wolny, 24.10.2014. 
innych osób z dn. 22.11.2013 r., zwana kolokwialnie „ustawą o przestępcach niebezpiecznych", „ustawą o zaburzonych”, „lex Trynkiewicz” czy nawet „ustawą o bestiach”. Regulacja ta weszła w życie na początku 2014 r. Powyższą ustawę stosuje się wobec osób, co do których zachodzi co najmniej wysokie prawdopodobieństwo popełnienia przestępstwa przeciwko życiu, zdrowiu lub wolności seksualnej drugiego człowieka z użyciem przemocy lub groźbą jej użycia. Czyn ten musi być obwarowany sankcją pozbawienia wolności, której górna granica wynosi co najmniej 10 lat, a objęte zakresem zastosowania normy mogą być osoby, które odbywały prawomocnie orzeczoną karę pozbawienia wolności lub karę 25 lat pozbawienia wolności, wykonywaną w systemie terapeutycznym. Konieczne jest również stwierdzenie u skazanych w toku postępowania wykonawczego zaburzeń psychicznych w postaci upośledzenia umysłowego, zaburzeń osobowości lub zaburzeń preferencji seksualnych ${ }^{4}$. Wzorem dla polskiego prawodawcy była regulacja prawna obowiązująca w Republice Federalnej Niemiec, dotycząca terapii i umieszczania w odpowiednim zakładzie sprawców czynów z użyciem przemocy o zakłóconych czynnościach psychicznych 5 .

Istnieją dwie możliwości zagwarantowania społeczeństwu bezpieczeństwa i zapobiegania ponownemu popełnieniu wyżej wymienionych czynów - mniej dolegliwy nadzór prewencyjny oraz całkowita izolacja osoby niebezpiecznej poprzez umieszczenie w Krajowym Ośrodku Zapobiegania Zachowaniom Dyssocjalnym, do którego trafił Mariusz T.6. Ustawa stanowi, że zakończenie odbywania kary pozbawienia wolności w zakładzie karnym nie stanowi przeszkody do orzekania o izolacji postpenalnej skazanego ${ }^{7}$, co budzi ogromne kontrowersje natury prawnej, poruszone takżew niniejszej pracy. W ośrodku mogą być umieszczone osoby, o których mowa w art. 14 ust. 3 „0 zaburzonych” ${ }^{\prime 8}$.Należy przyjrzeć się bliżej warunkom, w jakich przebywają osoby poddane przymusowej terapii.lzolowani mają całkowity zakaz samowolnego oddalania się, nad porządkiem w ośrodku czuwają specjalne służby zwane w ustawie ochrona a cały teren placówki jest monitorowany9. Ośrodek, mieszczący się obecnie w Gostyninie, jest podmiotem leczniczym, podległym ministrowi właściwemu do spraw zdrowia, a celem przebywania w nim osób z zaburzeniami psychicznymi jest poddanie ich odpowiedniej terapii, która umożliwi im późniejsze normalne funkcjonowanie w społeczeństwie. Postępowanie terapeutyczne ma na celu przede wszystkim poprawę stanu zdrowia osób izolowanych ${ }^{10}$. Jednakże wobec osób przebywających w placówce można stosować nie tylko środki lecznicze, ale także środki przymusu bezpośredniego, które polegają na użyciu siły fizycznej, na przykład poprzez założenie kajdanek, użycie pasów bezpieczeństwa czy nawet zastosowanie ręcznego miotacza substancji obezwładniających albo podanie leków uspokajających ${ }^{11}$. Jak wynika z powyżej przytoczonych regulacji, warunki izolacji są dla osób umieszczonych w ośrodku dość dotkliwe, ponieważ zakładają pełne ograniczenie ich wolności i pełną kontrolę ze strony pracowników ośrodka. Jednakże niewątpliwą zaletą jest skuteczne odizolowanie osób niebezpiecznych od społeczeństwa, co gwarantuje obywatelom niemalże stuprocentowe bezpieczeństwo. Podkreśla się także, że ochrona społeczeństwa nie jest jedynym celem stosowania mechanizmu izolacji postpenalnej - ma ona na celu także ochronę sprawcy, który kończąc odbywanie kary i opuszczając zakład karny, może być narażony na skierowane ku niemu wrogie zachowania innych osób i agresję ze strony innych członków społeczeństwa, co może prowadzić nie tylko do zagrożenia poczucia bezpieczeństwa byłego osadzonego, ale także do zagrożenia jego życia i zdrowia. Z kolei po odbyciu przez osobę niebezpieczną terapii w ośrodku reakcje obywateli powinny - przynajmniej teoretycznie-znacznie osłabnąćc ${ }^{12}$.

Drugą metodą na zapewnienie społeczeństwu bezpieczeństwa jest nadzór prewencyjny, znacznie mniej dotkliwy niż pełna izolacja byłego więźnia w ośrodku, sprawowany przez komendanta Policji - powiatowego, miejskiego lub rejonowego.Mogą być nim objęte osoby, o których mowa w art. 14 ust. 2 ustawy „, zaburzonych”.Nadzór prewencyjny polega na tym, że osoba, wobec której zostałon zastosowany, ma obowiązek informowania komendanta Policji o każdej zmianie swojego miejsca stałego pobytu czy miejsca zatrudnienia, a także o zmianie swojego imienia i nazwiska. Komendant może zażądać również informowania o miejscu aktualnego lub zamierzonego pobytu oraz o terminie i miejscu każdego wyjaz-

4 Art. 1, ustawa z dn. 22.11.2013 r. o postępowaniu wobec osób z zaburzeniami psychicznymi stwarzających zagrożenie życia, zdrowia lub wolności seksualnej innych osób (Dz.U. z 2014 r., poz. 24).

5 Zob. M. Królikowski, A. Sakowicz, Granice legalności postpenalnej detencji sprawców niebezpiecznych, „Forum Prawnicze” 2013, nr 5(19), s. 19.

6 Art. 3, ustawa o postępowaniu wobec osób z zaburzeniami psychicznymi, dz. cyt.

7 Art. 10 ust. 2, ustawa o postępowaniu wobec osób...

8 Art. 14 ust. 3, ustawa o posteppowaniu wobec osób..

9 Art. 6-7, ustawa o postępowaniu wobec osób...

10 Art. 4 -5, 25, ustawa o postępowaniu wobec osób...

11 Art. $34-45$, ustawa o postępowaniu wobec osób...

12 Zob. M. Królikowski, A. Sakowicz, dz. cyt., s. 20. 
du. Policja przeprowadza także czynności operacyjno-rozpoznawcze oraz weryfikuje, gromadzi i przetwarza informacje zebrane w toku postępowania operacyjno-rozpoznawczego.Ustawa przewiduje również możliwość zarządzenia kontroli operacyjnej. Postanowienie w tym przedmiocie wydaje sąd na pisemny wniosek komendanta wojewódzkiego Policji, za zgodą prokuratora okręgowego ${ }^{13}$.Jednakże nadzór prewencyjny wydaje się być mniej skuteczny niż pełna izolacja skazanego i nie daje społeczeństwu pełnej gwarancji na powstrzymanie osoby z zaburzeniami przed ponownym dokonaniem czynu zabronionego. Sama ustawa wskazuje, iż ma on na celu jedynie ograniczenie zagrożenia życia, zdrowia i wolności seksualnej innych osób ${ }^{14}$, nie jest to więc całkowita eliminacja niebezpieczeństwa. Zarówno w przypadku nadzoru prewencyjnego, jak i umieszczenia osoby „zaburzonej” w ośrodku izolacyjnym sąd wydaje orzeczenie bez podania terminu, co budzić może liczne kontrowersje natury prawnej i psychologicznej - czas trwania nadzoru czy izolacji może bowiem przeciaggać się nawet do śmierci sprawcy.

Należy dodać również, że nie tylko „ustawa o zaburzonych" przewiduje izolowanie osób, które odbyły już karę orzeczoną prawomocnym wyrokiem sądu. Ustawodawca wprowadza takie możliwości także w Kodeksie karnym, nazywając je „środkami zabezpieczającymi”. Wymienia się wśród nich umieszczenie w zakładzie zamkniętym i skierowanie na leczenie ambulatoryjne ${ }^{15}$. W art. 95a Kodeksu karnego w przypadku sprawcy skazanego na karę pozbawienia wolności bez jej warunkowego zawieszenia, który dopuścił się przestępstwa skierowanego przeciwko wolności seksualnej innych osób, w związku z zaburzeniami preferencji seksualnych, ustawodawca przewiduje możliwość umieszczenia sprawcy w zakładzie zamkniętym lub możliwość skierowania go na leczenie ambulatoryjne i przymusową terapię farmakologiczną lub psychoterapię. Środki te mają na celu obniżenie zaburzonego popędu seksualnego sprawcy i zapobieżenie ponownemu popełnieniu przez niego przestępstwa ${ }^{16}$. Regulacja zawarta w Kodeksie karnym ma więc taki sam cel jak normy zawarte $\mathrm{w}$ ustawie z 2013 roku i jest $\mathrm{w}$ istocie do nich podobna, chociaż różni się od regulacji zawartej w ustawie o zaburzonych tym, że sąd orzeka jednocześnie z wydawaniem wyroku skazującego na pobyt $\mathrm{w}$ zakładzie karnym - nie jest to więc orzekanie o izolacji osoby, która karę już odbyła, nie narusza również zakazu retroakcji ani zakazu podwójnego karania.Warto wspomnieć, że izolacja postpenalna nie jest instytucją nowąi charakterystyczną wyłącznie dla polskiego porządku prawnego. Podobne regulacje obowiązują bowiem między innymi w Niemczech, Belgii, Norwegii, Danii, Stowacji, Szwajcarii czy Włoszech ${ }^{17}$.

\section{KONTROWERSJE NATURY PRAWNEJ ZWIĄZANE Z OBOWIĄZYWANIEM USTAWY "O ZABURZONYCH"}

Omawiana ustawa budzi liczne kontrowersje natury prawnej - wartym przeanalizowania przykładem jest stanowisko Helsińskiej Fundacji Praw Człowieka, która niejednokrotnie wskazywała na liczne błędy w polskim ustawodawstwie w tym zakresie. Już w czerwcu 2013 r. przedstawiciele Fundacji wypowiadali się na temat projektu ustawy o „zaburzonych" przygotowanego przez Ministerstwo Sprawiedliwości, wskazując na jej zbyt szeroki zakres podmiotowy. Jak wynika z materiałów przedstawianych przez Fundację, celem Ministerstwa Sprawiedliwości było przygotowanie regulacji obejmującej głównie osoby, które dzięki amnestii w 1989 r. uniknęły kary śmierci, a zostały skazane na karę 25-letniego pozbawienia wolności. Ustawa natomiast przewiduje objęcie zakresem podmiotowym wszystkich skazanych, którzy odbyli już karę za przestępstwo przeciwko zdrowiu, życiu i wolności seksualnej innych osób, jeżeli stwierdzono u nich zaburzenia psychiczne w postaci upośledzenia umysłowego, zaburzenia osobowości czy też zaburzenia preferencji seksu$a \operatorname{lnych}^{18}$. Jest to zatem zbyt dalekie posunięcie ze strony prawodawcy, niespehniające pierwotnie poczynionych przez niego założeń. Prawnicy zatrudnieni przez Fundację powołują się na opinię wydaną przez Rzecznika Praw Obywatelskich, Irenę Lipowicz, i mówią o zbyt małym zróżnicowaniu między przesłankami dającymi podstawę do umieszczenia danej osoby w ośrodku a przesłankami umożliwiającymi stosowanie jedynie nadzoru prewencyjnego. W przypadku nadzoru

13 Postanowienie można wydać w przypadku trudności w weryfikacji informacji zebranych w toku postępowania operacyjno-rozpoznawczego lub w przypadku uzasadnionej obawy czynienia przez osobę, wobec której zastosowano nadzór prewencyjny, przygotowań do popełnienia przestępstwa przeciwko zdrowiu i życiu, zagrożonego karą pozbawienia wolności, której górna granica wynosi minimum 5 lat, lub przestępstwa przeciwko wolności seksualnej i obyczajności.

14 Art. 22 ust. 1, ustawa o postępowaniu wobec osób...

15 Art. 93, ustawa z dn. 6.06.1997r. - Kodeks karny (Dz.U. z 1997 r. Nr 88, poz. 553 z późn. zm.).

16 Art. 95a, ustawa zdn. 6.06.1997r...

17 Zob. M. Królikowski, A. Sakowicz, dz. cyt., s. 20.

18 Opinia HFPC w sprawie projektu ustawy o postępowaniu wobec osób zaburzonych, http://programy.hfhr.pl/monitoringprocesulegislacyjnego/opiniahfpc-w-sprawie-projektu-ustawy-o-postepowaniu-wobec-osob-zaburzonych/, 24.10.2014. 
prewencyjnego wystarczy bowiem przesłanka wysokiego prawdopodobieństwa popełnienia tego samego czynu, natomiast, aby orzec izolację skazanego w ośrodku, prawdopodobieństwo to musi być bardzo wysokie. Istnieje ryzyko, że w razie wątpliwości sądy mogą częściej decydować się na umieszczenie skazanego w ośrodku19. Psychiatrzy natomiast podkreślają, że nie istnieją metody, które pozwoliłyby na oszacowanie tego prawdopodobieństwa, a proponowana przez ustawodawcę izolacja może nie przynosić pożądanych rezultatów.Fundacja wskazuje także na zbyt wąski katalog środków, które umożliwiałyby resocjalizację osób izolowanych oraz zbyt szeroki katalog środków bezpośredniego przymusu. Izolacja postpenalna może stanowić zatem nie tyle leczenie „zaburzonego" sprawcy, co jego „przetrzymywanie” w ośrod$\mathrm{ku}$, a to z kolei stanowić może poważne pogwałcenie konstytucyjnych wolności i praw człowieka i obywatela, zwłaszcza nietykalności i wolności osobistej. Przedstawiciele Fundacji twierdzą również, że opinie lekarzy psychiatrów nie zostały należycie uwzględnione, a „przymusowa terapia osobowości" nie przyniesie oczekiwanych skutków i nie daje szans na powrót jednostki do normalnego funkcjonowania w społeczeństwie. Według nich powyższa regulacja stanowi jedynie pretekst do dalszej izolacji osób skazanych, naganna jest także możliwość ich dożywotniego izolowania ${ }^{20}$.

Analizowana regulacja prawna może być sprzeczna również z Konwencją o Ochronie Praw Człowieka i Podstawowych Wolności. Art. 7 Konwencji, dotyczący zakazu karania bez postawy prawnej, stanowi bowiem: „nikt nie może być uznany za winnego popełnienia czynu polegającego na działaniu lub zaniechaniu działania, który według prawa wewnętrznego lub międzynarodowego nie stanowił czynu zagrożonego karą w czasie jego popełnienia. Nie będzie również wymierzona kara surowsza od tej, którą można było wymierzyć w czasie, gdy czyn zagrożony karą został popełniony". "Lex Trynkiewicz" może więc istotnie naruszać bezwzględny zakaz retroakcji w prawie karnym, zawarty nie tylko w krajowym porządku normatywnym, ale także w prawie międzynarodowym - na mocy powyższej Konwencji. We wprowadzonej nową ustawą regulacji prawnej można dostrzec również naruszenie jednej z podstawowych funkcji kary - a mianowicie funkcji resocjalizacyjnej, zwanej inaczej funkcją wychowawczą. Kara ma bowiem doprowadzić sprawcę do przestrzegania istniejącego porządku prawnego i społecznego oraz w miarę możliwości zagwarantować możliwość normalnego funkcjonowania w społeczeństwie.

Ustawa o „zaburzonych” budzi szereg zastrzeżeń formułowanych przez prawników. Po pierwsze, wskazuje się na jej sprzeczność z zakazem retroakcji w prawie karnym. Zasada ta stanowi, że osoby popełniające czyn zabroniony są sądzone na podstawie przepisów obowiązujących $\mathrm{w}$ chwili popetnienia przestępstwa, chyba że nowe przepisy są dla nich względniejsze. W przypadku stosowania ustawy „o zaburzonych” skazani dokonali czynów zabronionych przed wejściem ustawy w życie, nie powinna mieć ona zatem zastosowania w ich przypadku. Z kolei zakaz działania prawa wstecz jest związany z konstytucyjną zasadą demokratycznego państwa prawnego, co może wskazywać na sprzeczność ustawy z Konstytucją. Po drugie, powyższa regulacja stoi w konflikcie z zakazem podwójnego karania za ten sam czyn, ponieważ skazani odbyli już karę w zakładzie karnym. Podobne zdanie ma na ten temat Krajowa Rada Sądownictwa, wskazując, że „ustawa budzi wattpliwości w zakresie respektowania podstawowych zasad prawa karnego: niedziałania prawa karnego wstecz oraz niekarania dwa razy za to samo przestępstwo" ${ }^{22}$. Powyższą regulację skrytykowała także Ewa Łętowska, była Rzecznik Praw Obywatelskich i sędzia Trybunału Konstytucyjnego w stanie spoczynku. Wyraża ona jasno swój pogląd, mówiąc: „Pozbawienie wolności - jakkolwiek nazwane: czy uwięzieniem, czy umieszczeniem na terapii - jest pozbawieniem wolności. I nie powinny być mu poddane te osoby, które już zostały ukarane ${ }^{\prime 2}$.E. Łętowska

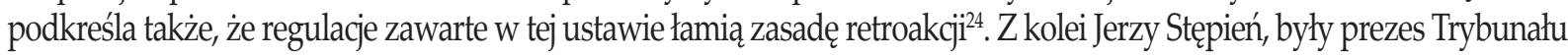
Konstytucyjnego, stwierdza, że „Konstytucja powinna chronić każdego, nawet zbrodniarza”25. Powołuje się on na art. 30 ustawy zasadniczej, ostro krytykując kolokwialną nazwę „ustawa o bestiach”, ponieważ każdy - nawet zbrodniarz jest osobą ludzka, której nie można odmówić przyrodzonej i niezbywalnej godności i nikogo nie można wyłączać spod obowiązywania tego przepisu.J. Stępień przypomina także dawne czasy, w których obowiązywała kategoria „osób wy-

19 RPO skierowała do Trybunału ustawę o postępowaniu wobec osób zaburzonych, http://programy.hfhr.pl/monitoringprocesulegislacyjnego/rpo-skierowala-do-trybunalu-ustawe-o-postepowaniu-wobec-osob-z-zaburzeniami-psychicznymi/, 24.10.2014.

20 Tamże.

21 Art. 7 - Konwencja o Ochronie Praw Człowieka i Podstawowych Wolności (Dz.U. z 1993 r. Nr 61, poz. 284).

22 J. Turczyk, Ustawa o bestiach - prezydent zlożyt wniosek do Trybunalu Konstytucyjnego, http://www.rmf24.pl/fakty/polska/news-ustawa-o-bestiachprezydent-zlozyl-wniosek-do-trybunalu,nId,1352046, 24.10.2014.

23 E. Siedlecka, Prof. Łętowska: Ustawa o „,bestiach” jest niedobra, http://wyborcza.pl/1,75478,15057004,Prof_Letowska_Ustawa_o_bestiach jest niedobra.html\#TRrelSST, 24.10.2014.

24 Zob. Tamże.

25 A. Siek, Stęień: Dlaczego nie ma wniosku do TK? Nie ma dziś ludzi wyjętych spod prawa, http://wiadomosci.gazeta.pl/wiadomosci /1,114871,15441224,Stepien_Dlaczego_nie_ma_wniosku_do_TK_Nie_ma_dzis.html, 24.10.2014. 
jętych spod prawa", wobec których mogła być zastosowana kara śmierci, jednocześnie podkreślając, że obecnie żyjemy w zupełnie innych warunkach i musimy inaczej patrzeć na osobę ludzka, pamiętając o doświadczeniach z XX wieku². Niewątpliwie należy przyznać rację konstytucjonalistom, ponieważ zasady ustanowione na mocy Konstytucji RP - takie jak nietykalność i wolność osobista, humanitarne traktowanie, wolność poruszania się czy wreszcie niezbywalna godność osoby ludzkiej - dotyczą każdego i nie mogą być ograniczane z naruszeniem przepisów ustawy zasadniczej.

Ustawa budzi także zastrzeżenia Ireny Lipowicz, Rzecznika Praw Obywatelskich. Jej zdaniem nie został zrealizowany podstawowy cel, dla którego ustawa „o zaburzonych" miała wejść w życie - czyli możliwość stosowania jedynie w przypadku sprawców najbardziej niebezpiecznych przestępstw. Podobnie jak przedstawiciele Helsińskiej Fundacji Praw Człowieka, obecna Rzecznik wskazuje, że „w ustawie zostały użyte zwroty niedookreślone w postaci wysokiego i bardzo wysokiego prawdopodobieństwa popełnienia określonego w ustawie rodzaju czynu zabronionego przez osobę, której dotyczy wniosek o uznanie jej za stwarzającą zagrożenie" ${ }^{\prime 27}$. I. Lipowicz podkreśla, że ustawa "nie daje jasnych i precyzyjnych narzędzi umożliwiających wytyczenie granicy pomiędzy wysokim a bardzo wysokim prawdopodobieństwem popełnienia określonych czynów zabronionych"28. Powyższy akt normatywny krytykuje również Maciej Bocheński w swojej pracy Populizm penalny w polskim wydaniu - rzecz o kryminologicznej problematyce ustawy o postepowaniu wobec osób stwarzających zagrożenie. W regulacjach przyjętych w innych krajach, takich jak Stany Zjednoczone, Kanada, Wielka Brytania, Australia czy Nowa Zelandia, istnieją „narzędzia do przewidywania ryzyka recydywy w sposób jak najbardziej precyzyjny (...), w oparciu o najlepsze dostępne dane dotyczące specyfiki sprawców przestępstw seksualnych" ${ }^{29}$, które w Polsce nie są niestety stosowane. Ponadto nie da się precyzyjnie ustalić, jakiego rodzaju karą zagrożony będzie czyn ewentualnie popełniony w przyszłości przez sprawcę $e^{30}$ Z wyżej przytoczonych wypowiedzi bezsprzecznie wynika, iż ustawodawca nie poradził sobie we właściwy sposób z postawionym przed nim zadaniem zapewnienia społeczeństwu bezpieczeństwa bez konieczności łamania podstawowych praw jednostek wymagających resocjalizacji.

Kolejne zarzuty wobec ustawy „o zaburzonych” formułują Michał Królikowski i Andrzej Sakowicz w swojej pracy Granice legalności postpenalnej detencji sprawców niebezpiecznych. Oprócz poruszonych już wyżej wymienionych kwestii wskazują także na „realnie podwójne ukaranie za ten sam czyn" ${ }^{\prime \prime 1}$, czyli na sprzeczność przepisów ustawy z zakazem podwójnego karania. Według M. Królikowskiego i A. Sakowicza rozwiązania wprowadzone w ustawie są nieproporcjonalne i zbędne, gdyż cel zabezpieczający można osiągną́ znacznie mniej inwazyjnymi środkami. Przywołują oni argument o zbytecznym obciążaniu administracji zakładów karnych oraz podkreślają - wielokrotnie w niniejszej pracy przywoływaną - obawę przed masową izolacją sprawców, którzy odbyli już karę orzeczoną prawomocnym wyrokiem sądu. Autorzy odwołują się również do licznych opinii psychiatrów, według których leczenie psychiatryczne zostaje wdrożone tam, gdzie jest „niemożliwe lub nieskuteczne ${ }^{\prime \prime 23}$. M. Królikowski i A. Sakowicz poddają w wątpliwość nie tylko regulację zawartą $\mathrm{w}$ „ustawie o zaburzonych”, ale także przepis zawarty w art. 95a Kodeksu karnego, przewidujący możliwość umieszczenia sprawcy w zakładzie zamkniętym lub skierowania na leczenie ambulatoryjne $\mathrm{w}$ formie terapii farmakologicznej lub psychoterapii już po odbyciu kary w zakładzie karnym. Zdaniem autorów „w przypadku zastosowania izolacji sprawcy nie jest ona zasadniczym celem wykonywania środków zabezpieczających" ${ }^{\prime \prime 3}$. Według A. Sakowicza i M. Królikowskiego przepis ten łamie dwutorowość środków prawnych stosowanych wobec przestępców cierpiących na zaburzenia psychiczne, określoną w Kodeksie karnym oraz ustawie o ochronie zdrowia psychicznego ${ }^{34}$. Podobnie jak przepisy ustawy o „zaburzonych", tak i regulacja zawarta w art. 95 Kodeksu karnego łączy funkcje przymusowej detencji psychiatrycznej oraz środka zabezpieczającego. Mimo wszystkich wyżej wymienionych sprzeczności w systemie prawa, ukazanych przez A. Sakowicza i M. Królikowskiego, w ich pracy możemy znaleźć następujące stwierdzenie: „Z pewnością jednak trudno oprzeć się wrażeniu, że podczas analizy omawianej problematyki docieramy do momentu, w którym klasyczne zasady prawa karnego i ochrony praw człowieka okazują się za krótkie, by w jednoznaczny sposób

26 Tamże.

27 Trybunał Konstytucyjny zajmie się , ustawą o bestiach”. ,Niedookreślone zwroty, brak jasnych narzędzi”, http://wyborcza.pl/1,75478,15988990, Trybunal_Konstytucyjny_zajmie_sie_ustawa_o_bestiach_.html, 24.10.2014.

28 Tamże.

29 Zob. M. Bocheński, Populizm penalny w polskim wydaniu - rzecz o kryminologicznej problematyce ustawy o postępowaniu wobec osób stwarzających zagrożenie, „e-Czasopismo Prawa Karnego i Nauk Penalnych” 2014, nr 2, s. 8-11.

30 Zob. Tamże, s. 8-11.

31 M. Królikowski, A. Sakowicz, dz. cyt., s. 18-19.

32 Tamże, s. 18-19.

33 Tamże, s. 20-22.

34 Tamże, s. 20-22. 
objąć przypadki skrajne. $\mathrm{W}$ takim momencie pozostaje zwrócenie się ku istocie prawa i jego wartościom, takim jak cel istnienia systemu prawnego. Nie zgadzamy się z taką interpretacja, w której absolutyzm standardów ochrony praw człowieka i resocjalizacyjna wizja postępowania ze sprawcami niebezpiecznymi, o których mowa w analizowanej ustawie, w trakcie wykonywania kary pozbawienia wolności czyniłyby nas bezradnymi wobec realnego niebezpieczeństwa, jakie współobywatelom grozi ze strony tych osób - im zaś ze strony społeczeństwa.Nie wydaje się też racjonalne wyrzeczenie się pewnego paternalizmu prawnego, który pozwala na postrzeganie umieszczenia w ośrodku jako podejmowanego dla dobra osoby z zaburzeniami psychicznymi stwarzającej zagrożenie życia, zdrowia lub wolności seksualnej innych osó$b^{\prime \prime 35}$. Tym samym A. Sakowicz i M. Królikowski dopuszczają możliwość istnienia w naszym systemie prawnym instytucji izolacji postpenalnej sprawców szczególnie niebezpiecznych. Jednakże podkreślają że zawarta w ustawie regulacja musi być interpretowana w sposób zawężający, zawszew zgodzie z ustawą zasadniczą.

Na konieczność obowiązywania ustawy o przestępcach niebezpiecznych wskazuje z kolei profesor Andrzej Zoll, były Rzecznik Praw Obywatelskich oraz były prezes Trybunału Konstytucyjnego, który ustawą „,nie jest zachwycony" ${ }^{\prime \prime 3}$, jednak „nie wyobraża sobie jej braku”37. W rozmowie z "Gazetą Wyborczą" A. Zoll podkreśla, że ustawa jest skutkiem zamiany kary śmierci na karę 25-letniego pozbawienia wolności w roku $1989 \mathrm{i}$ braku kary dożywotniego pozbawienia wolności w polskim porządku prawnym w tym okresie. Według byłego Rzecznika Praw Obywatelskich regulacja ta nie narusza zakazu podwójnego karania, ponieważ nie odwołuje się do popełnionego przed laty czynu, ale do obecnego stanu sprawcy. A. Zoll mówi także, że „mamy do czynienia z osobami rzeczywiście niebezpiecznymi”"38 oraz że jest to „działanie w stanie wyższej konieczności" ${ }^{\prime 39}$. Dopuszcza także możliwość stwierdzenia niekonstytucyjności ustawy przez Trybunał Konstytucyjny, jednakże podkreśla, iż wolałby ryzykować niekonstytucyjnością regulacji prawnej, a nie bezpieczeństwem społeczeństwa i życiem obywateli. Jego zdaniem nadzór prewencyjny, którego stosowanie proponowała Helsińska Fundacja Praw Człowieka, jest niewystarczający i nie gwarantuje pełnego bezpieczeństwa społeczneg0 $0^{40}$.Podobne opinie stanowią jednak mniejszość wśród opinii polskich konstytucjonalistów i karnistów, ponieważ wydają się one hołdować maksymie "„el uświęca środki” i zezwalać na łamanie podstawowych zasad konstytucyjnych oraz zasad prawa karnego w sytuacji „,wyższej potrzeby".

\section{INNE MOŻLIWOŚCI ZAGWARANTOWANIA OCHRONY SPOŁECZNEJ}

Przedstawiciele Helsińskiej Fundacji Praw Człowieka proponują wprowadzenie innych rozwiązań, które mogłyby chronić społeczeństwo przed ponownym popełnieniem czynu zabronionego przez osobę, która opuściła zakład karny. Jest to $\mathrm{m}$. in. stosowanie nieizolacyjnych środków kontroli, jak na przykład wprowadzenie elektronicznego systemu dozoru. Zdaniem osób reprezentujących Fundację zastosowane przez ustawodawcę rozwiązania są nieproporcjonalne do istniejącego zagrożenia ${ }^{41}$. Również według Pawła Moczydłowskiego, znanego kryminologa, istnieją znacznie mnie dotkliwe środki, które zapewniłyby porządek społeczny i bezpieczeństwo publiczne. P. Moczydłowski jako przykład podał możliwość ustanowienia opiekunów socjalnych, którzy pracowaliby z byłymi więźniami, a Krajowy Ośrodek Zapobiegania Zachowaniom Dyssocjalnym nazywa „quasi-więzieniem, które chce się nazwać quasi-szpitalem" ${ }^{\text {"22 }}$. Z kolei Janusz Heitzman, znany psychiatra,podkreśla bezzasadność istnienia instytucji izolacji postpenalnej: „ta ustawa mówi o terapii, ale chodzi o izolację. Izolacja to nie leczenie, to kara. Ma być wymierzona nie za czyn popetniony, ale za prawdopodobieństwo jego popełnienia. Ci ludzie spędzili w więzieniu długie lata. Można ich było poddawać terapii. Jeśli nie poddano, widać nie była potrzebna. Jeśli poddano, okazała się nieskuteczna, skoro chce się ich nadal izolować. Więc nie ma uzasadnienia dla dalszej terapii" ${ }^{43}$. Natomiast Błażej Kmieciak, doktor nauk prawnych oraz członek Polskiego Towarzystwa Psychiatrycznego, powołuje sięna możliwośćnałożenia na osobę stwarzającą zagrożenie obowiązku poddania się odpowied-

35 Tamże, s. 33-34.

36 E. Siedlecka,Skazanina karesśsmierci wyjdą zięzień. Prof.Zoll:Dozórnie wystarczy.Potrzebnajestizolacja, http://wyborcza.pl/1,76842,14946931,Skazani_na kare_smierci_wyjda_z_wiezien_Prof_Zoll_html, 24.10.2014.

$3 \overline{7}$ Tamże.

38 Tamże.

39 Tamże.

40 Zob. Tamże.

41 Apel do prezydenta o skierowanie ustawy o izolacji osób stwarzajacych zagrożenie, http://programy.hfhr.pl/monitoringprocesulegislacyjnego/apel-doprezydenta-o-skierowanie-ustawy-o-izolacji-osob-stwarzajacych-zagrozenie-do-tk/, 24.10.2014.

42 TVP Info, Dr Paweł Moczydtowski m.in. o nadzorze nad ,,bestiami”, http:/www.youtube.com/watch?v=KEKbjCaSkKM, 24.10.2014.

43 E. Siedlecka, Prof. Heitzman: Psychiatria nie odpowiada za bestie, http://m.wyborcza.pl/wyborcza/1,105402,15008124,Prof_Heitzman_Psychiatria_nie_odpowiada_za_bestie_html, 24.10.2014. 
niemu postępowaniu terapeutycznemu jednocześnie z zastosowaniem wobec niej nadzoru prewencyjnego. B. Kmieciak podkreśla także, że „,dostrzegalnym problememnie jest wyłącznie kwestia zagwarantowaniaspołecznego bezpieczeństwa w sytuacii, gdy więzieniaopuszczają nadal niebezpieczne osoby. Wydaje się, żerównie istotne jest zagadnienie stworzenia prawnych(instytucjonalnych) oraz terapeutycznych rozwiązańumożliwiających kontynuowanie działań korekcyjnychw warunkach wolnościowych"44. Jak widać na powyższych przykładach, wprowadzanie izolacji postpenalnej jest z punktu widzenia medycznego i psychologicznego bezzasadne, a sprawcy czynów zabronionych winni być poddani stosownemu leczeniu już podczas pobytu w zakładzie karnym - w przeciwnym wypadku jest to czas stracony, nic nie wnoszący do resocjalizacji skazanego.

Helsińska Fundacja Praw Człowieka podjęła wiele kroków mających na celu zmianę istniejącego stanu prawnego. Wnioski o skierowanie ustawy o „zaburzonych” do Trybunału Konstytucyjnego otrzymał Rzecznik Praw Obywatelskich, Prokurator Generalny oraz Prezydent RP ${ }^{45}$. Bronisław Komorowski i Irena Lipowicz skierowali swoje wnioski do Trybunału Konstytucyjnego. Ciekawy jest fakt, że to sam Mariusz T. zwrócił się do Fundacji z prośbą o pomoc. Adam Bodnar, wiceprezes Fundacji, w rozmowie z „Gazetą Wyborczą” mówił, że ustawa jest sprzeczna z Konstytucją i że może mieć negatywne konsekwencje dla resocjalizacji skazanego. Naruszona została bowiem zasada, według której sprawca rozlicza się ze społeczeństwem, ponosząc wymierzoną mu karę, a następnie może mieć szansę na życie jako wolny człowiek. A. Bodnar wskazuje również, podobnie jak Irena Lipowicz, na złamanie zasady określoności prawa, ponieważ nie podano dokładnych przesłanek, na podstawie których sąd i biegli mają oceniać, czy zachodzi „,bardzo wysokie” prawdopodobieństwo ponownego popełnienia przez sprawcę podobnego czynu. Wiceprezes Fundacji ma także zastrzeżenia co do samego postępowania w sprawie dotyczącej Mariusza T. Jego zdaniem błędem jest wydanie opinii przez biegłych po jednorazowym kontakcie ze skazanym oraz fakt, że opinię wydał psycholog-seksuolog, a nie lekarz seksuolog, jak w sprawach karnych, mimo że - podobnie jak w postępowaniu karnym - chodzi o pozbawienie człowieka wolności ${ }^{46}$.

Co ciekawe, mimo tak licznych zarzutów podnoszonych przez Helsińską Fundację Praw Człowieka oraz autorytety nauk prawnych, zwłaszcza specjalistów w dziedzinie prawa karnego, jedynie trzech posłów sprzeciwiło się uchwaleniu tej ustawy, którą można nazwać - opierając się na przytoczonych w niniejszej pracy argumentach padających z ust prawników -bublem legislacyjnym ${ }^{47}$. Ciekawy jest fakt, że Prezydent podpisał ustawę, po czym już podpisany akt normatywny zaskarżył do Trybunału Konstytucyjnego ${ }^{48}$. Jest to kontrowersyjna decyzja głowy państwa, ponieważ w toku procesu ustawodawczego Prezydent może skierować do Trybunału Konstytucyjnego wniosek o zbadanie zgodności aktu prawnego z ustawą zasadnicza, czego nie zrobił. Budzi to wątpliwość, czy omawiana ustawa została przez niego dokładnie zbadana $\mathrm{w}$ toku procesu legislacyjnego, czy też weszła ona w życie w warunkach zbiorowej paniki w związku ze zbliżającym się opuszczeniem zakładu karnego przez Mariusza T., a dokładną jej weryfikację odłożono w czasie.

Musimy pamiętać, że Mariusz T. nie jest jedyną osoba, wobec której stosuje się tego rodzaju „środek zapobiegawczy”. Według danych podawanych przez „Gazetę Wyborczą" do sądów spłynęły już wnioski w sprawie 27 osób, mimo że ustawę uchwalono, aby zapobiec swobodnemu wyjściu z zakładów karnych osób, którym w wyniku amnestii karę śmierci zamieniono na karę dwudziestopięcioletniego pozbawienia wolności, a - według danych podawanych przez gazetę obecnie możemy wskazać najwyżej trzy takie osoby, które w najbliższym czasie opuszczą zakłady karne ${ }^{49}$. Przykładem jest wniosek o izolację Eweliny C., skazanej na 6 lat pozbawienia wolności za usiłowanie zabójstwa niemowlęcia, obecnie podlegającej nadzorowi prewencyjnemu. Jednak kryminolog P. Moczydłowski uważa, że kobieta nie powinna w ogóle trafić do więzienia, lecz winna być umieszczona w zakładzie psychiatrycznym ${ }^{50}$. Orzekanie o umieszczeniu w ośrodku staje się więc czymś w rodzaju korektynie do końca poprawnych wyroków sądów. W trzech innych sprawach sąd orzekł

44 B. Kmieciak, Prawnopsychiatryczny kontekst wprowadzenia przepisów zezwalajacych na detencję niepsychotycznych sprawców, „Forum Prawnicze” 2013, nr 6 (20), s. 41.

45 HFPC do prokuratora generalnego ws. ustawy o nadzorze nad zabójcami, http://prawo.rp.pl/artykul/1083524.html?print=tak\&p=0, 24.10.2014.

46 E. Siedlecka, Fundacja Helsinska: Sprawa Trynkiewicza powinien zajać się Trybunat Konstytucyjny, http://wyborcza.pl/1,75478,15406456,Fundacja_Helsinska_Sprawa_Trynkiewicza_powinien_zajac.html, 24.10.2014.

47 E. Siedlecka., Sejm przyjąt kontrowersyjna ustawe o izolacji niebezpiecznych przestępców. Tylko troje postów przeciw, http://wyborcza. pl/1,75478,14830725,Sejm_przyjal_kontrowersyjna_ustawe_o_izolacji_niebezpiecznych.html, 24.10.2014.

48 JS, Prezydent podpisat ustawe, ale... skierowat ją do Trybunału Konstytucyjnego, http://wyborcza.pl/1,75478,15134263,Prezydent_podpisal_ustaweo bestiach ale skierowal.html, 24.10.2014.

49 E. Siedlecka, Ustawa o bestiach niekonstytucyjna? Sad pyta Trybunat o opinię, http://wyborcza.pl/1,76842,15906245,Ustawa_o_bestiach_niekonstytucyjna_Sad_pyta_Trybunal.html, 24.10.2014.

50 P. Kozioł, Cisnęła dzieckiem. Pierwsza kobieta objęta tzw. ,ustawa o bestiach”, http://wiadomosci.wp.pl/kat,1342,title,Cisnela-dzieckiem-Pierwsza-ko bieta-objeta-tzw-ustawa-o-bestiach,wid,16499520,wiadomosc.html?ticaid=112eal\&_ticrsn=5, 24.10.2014. 
już umieszczenie w Krajowym Ośrodku Zapobiegania Zachowaniom Dyssocjalnym, w jednej - nadzór prewencyjny ${ }^{51}$. W sprawie ustawy „o bestiach” orzeknie Trybunał Konstytucyjny, może okazać się zatem, że obecne orzeczenia są wydawane sprzecznie z prawem.

\section{Podsumowanie}

Przyjmowane w pośpiechu i ogólnej panice opinii publicznej „lex Trynkiewicz” budzi wiele kontrowersji natury prawnej. Przede wszystkim wskazuje się na sprzeczność ustawy „, zaburzonych" z Konstytucją Rzeczypospolitej, a także z prawem międzynarodowym i ratyfikowaną przez Polskę Konwencją o Ochronie Praw Człowieka i Podstawowych Wolności. Wątpliwości budzi zwłaszcza możliwość złamania zakazu retroakcji w prawie karnym, a także zakazu podwójnego karania. Możliwa jest także niezgodność ustawy z podstawowymi funkcjami prawa i funkcjami kary - przede wszystkim z funkcją resocjalizacyjną oraz funkcją wychowawczą. Kara pozbawienia wolności ma bowiem na celu przywrócenie osoby skazanej do życia w społeczeństwie, a nie skierowanie jej na dalszy pobyt w ośrodku izolacyjnym. Kontrowersje budzi również aspekt psychologiczny - nie da się bowiem precyzyjnie stwierdzić, czy dana osoba po raz kolejny popełni czyn zabroniony oraz czy izolacja postpenalna przyniesie w jej przypadku jakiekolwiek skutki. Terapia natomiast powinna być stosowana już podczas odbywania wyroku w zakładzie karnym - w przeciwnym wypadku powyższa kara nie spełnia swoich podstawowych funkcji.

Istnieje także wiele innych możliwości zapewnienia społeczeństwu bezpieczeństwa, znacznie mniej dotkliwych i nienaruszających zakazu podwójnego karania za ten sam czyn. Wśród nich wymienia się m.in.: nadzór prewencyjny, dozór elektroniczny czy też ustanowienie opiekunów społecznych. Trzeba również wspomnieć o tym, że błędem było już samo uchwalenie ustawy amnestyjnej w 1989 w obowiązującym kształcie. O wiele lepszym, niepowodującym problemów w stosowaniu prawa obecnie, rozwiązaniem byłaby zamiana kary śmierci na karę dożywotniego pozbawienia wolności, a nie na karę 25-letniego pobytu w zakładzie karnym, jednak prawodawca nie znowelizował w porę Kodeksu karnego. W obecnej sytuacji wymiar sprawiedliwości musi poradzić sobie z problemem zagrożenia, jakie mogą stwarzać opuszczający zakłady karne niebezpieczni przestępcy. Czy właściwym rozwiązaniem było uchwalenie ustawy „o bestiach” - zadecyduje Trybunał Konstytucyjny.

\section{Akty prawne:}

[1] Ustawa z dn. 6.06.1997 r. - Kodeks karny (Dz.U. z 1997 r. Nr 88, poz. 553 z późn. zm.)

[2] Konwencja o Ochronie Praw Człowieka i Podstawowych Wolności (Dz.U. z 1993 r. Nr 61, poz. 284)

[3] Ustawa z dn. 22.11.2013 r. o postępowaniu wobec osób z zaburzeniami psychicznymi stwarzających zagrożenie życia, zdrowia lub wolności seksualnej innych osób (Dz.U. z 2014 r., poz. 24)

\section{BibliogRAFIA:}

[4] Bocheński M., Populizm penalny w polskim wydaniu - rzecz o kryminologicznej problematyce ustawy o postępowaniu wobec osób stwarzajacych zagrożenie, „e-Czasopismo Prawa Karnego i Nauk Penalnych" 2014, nr 2

[5] Kmieciak B., Prawnopsychiatryczny kontekst wprowadzenia przepisów zezwalających na detencję niepsychotycznych sprawców, „Forum Prawnicze” 2013, nr $6(20)$

[6] Królikowski M., Sakowicz A., Granice legalności postpenalnej detencji sprawców niebezpiecznych, „Forum Prawnicze” 2013, nr 5(19)

\section{NetOGRAFiA:}

[7] Apel do prezydenta o skierowanie ustawy o izolacji osób stwarzajacych zagrożenie, http://programy.hfhr.pl/monitoringprocesulegislacyjnego/apeldo-prezydenta-o-skierowanie-ustawy-o-izolacji-osob-stwarzajacych-zagrozenie-do-tk/, 24.10.2014

[8] Dr Paweł Moczydłowski m.in. o nadzorze nad "bestiami", http://www.youtube.com/watch?v=KEKbjCaSkKM, 24.10.2014

[9] HFPC do prokuratora generalnego ws. ustawy o nadzorze nad zabójcami, http://prawo.rp.pl/artykul/1083524.html?print=tak\&p=0, 24.10.2014

[10] Kacprzak I., Zawadka G., Trynkiewicz wolny i bez zarzutóww, www.rp.pl/artykul/1086195.html, 24.10.2014

[11] Kozioł P., Cisnęta dzieckiem. Pierwsza kobieta objęta tzw. ," ustawa o bestiach", http://wiadomosci.wp.pl/kat,1342, title,Cisnela-dzieckiem-Pierwszakobieta-objeta-tzw-ustawa-o-bestiach,wid,16499520,wiadomosc.html?ticaid=112ea1\&_ticrsn=5, 24.10.2014

[12] Mariusz Trynkiewicz nie powinien być wolny, www.polskieradio.pl/5/3/Artykul/1043948,Biegli-Mariusz-Trynkiewicz-nie-powinien-byc-wolny, 24.10.2014

[13] Opinia HFPC w sprawie projektu ustawoy o postępowaniu wobec osób zaburzonych, http://programy.hfhr.pl/monitoringprocesulegislacyjnego/opinia-hfpc-w-sprawie-projektu-ustawy-o-postepowaniu-wobec-osob-zaburzonych/, 24.10.2014

[14] Prezydent podpisal ustawe, ale... skierowat ja do Trybunatu Konstytucyjnego, http://wyborcza.pl/1,75478,15134263,Prezydent_podpisal_ustawe_o_bestiach_ale__skierowal.html, 24.10.2014

51 E. Siedlecka, dz. cyt., 24.10.2014. 
[15] Radlińska E., Moratorium na karę śmierci bez dożywocia było błędem, www.prawo.gazetaprawna.pl/wywiady/675805,moratorium_na_kare_ smierci_bez_dozywocia_bylo_bledem.html, 24.10.2014

[16] RPO skierowała do Trybunału ustawe o postępowaniu wobec osób zaburzonych, http://programy.hfhr.pl/monitoringprocesulegislacyjnego/rposkierowala-do-trybunalu-ustawe-o-postepowaniu-wobec-osob-z-zaburzeniami-psychicznymi/, 24.10.2014

[17] Siedlecka E., Prof. Łętowska: Ustawa o "bestiach" jest niedobra, http://wyborcza.pl/1,75478,15057004,Prof_Letowska_Ustawa_o_bestiach_ jest_niedobra.html\#TRrelSST, 24.10.2014.

[18] Siedlecka E., Fundacja Helsinska: Sprawą Trynkiewicza powinien zając się Trybunał Konstytucyjny, http://wyborcza.pl/1,75478,15406456,Fundacja_Helsinska_Sprawa_Trynkiewicza_powinien_zajac.html, 24.10.2014

[19] Siedlecka E., Prof. Heitzman: Psychiatria nie odpowiada za bestie, http://m.wyborcza.pl/wyborcza/1,105402,15008124,Prof_Heitzman_Psychiatria_nie_odpowiada_za_bestie_html, 24.10.2014

[20] Siedlecka E., Sejm przyjąt kontrowersyjna ustawe o izolacji niebezpiecznych przestępców. Tylko troje postów przeciw, http://wyborcza. pl/1,75478,14830725,Sejm_przyjal_kontrowersyjna_ustawe_o_izolacji_niebezpiecznych.html, 24.10.2014

[21] Siedlecka E., Skazani na karéśmierciwyjjda z więzień. Prof. Zoll:Dozór nie wystarczy. Potrzebnajestizolacja, http://wyborcza.pl/1,76842,14946931,Skazani_na_kare_smierci_wyjda_z_wiezien_Prof_Zoll_html, 24.10.2014

[22] Siedlecka E., Ustawa o bestiach niekonstytucyjna? Sad pyta Trybunał o opinie, http://wyborcza.pl/1,76842,15906245,Ustawa_o_bestiach_niekonstytucyjna_Sad_pyta_Trybunal.html, 24.10.2014

[23] Siek A., Stępień:Dlaczegonie ma wniosku do TK? Nie ma dziś ludzi wyjętych spod prawa, http://wiadomosci.gazeta.pl/wiadomosci /1,114871,15441224,Stepien_Dlaczego_nie_ma_wniosku_do_TK_Nie_ma_dzis.html, 24.10.2014

[24] Trybunat Konstytucyjny zajmie się „ustawą o bestiach”. „Niedookrélone zworoty, brak jasnych narzędzi", http://wyborcza.pl/1,75478,15988990,Trybunal_Konstytucyjny_zajmie_sie_ustawa_o_bestiach_.html, 24.10.2014

[25] Turczyk J., Ustawa o bestiach - prezydent złożyt wniosek do Trybunału Konstytucyjnego, http://www.rmf24.pl/fakty/polska/news-ustawa-obestiach-prezydent-zlozyl-wniosek-do-trybunalu,nId,1352046, 24.10.2014 